\title{
Candida tropicalis sp. Nov., a novel, zinc-enriched yeast species found in China
}

\author{
Yu SU ${ }^{1 *}$, Jian-Ning ZHU², Xiao-Ru LI ${ }^{1}$, Xin-Guo ZHANG ${ }^{1 *}$ (D), Ming FENG ${ }^{1}$, Nan WANG ${ }^{1}$, Wen-Jie LIU ${ }^{1}$
}

\begin{abstract}
Zinc is one of the most important trace elements and deficiency can lead to significant clinical complications. Microbial transformation is one of the most important methods used to supplement organic zinc and there may be some naturally occurring microorganisms that have both higher zinc tolerances and transformation capabilities. In this study, microorganisms which displayed such characteristics were widely screened, and a strain designated T-A was found. Morphological and molecular determination demonstrated that T-A is closely related to Candida tropicalis with $87 \%$ of $18 \mathrm{~S} \mathrm{rDNA}$ homology, with a G+C content measured by RP-HPLC of $88.42 \%$. Candida tropicalis sp. T-A strains were shown to grow and transform zinc best at pH5 in medium with a zinc ion concentration of $8000 \mu \mathrm{g} / \mathrm{mL}$ at $28^{\circ} \mathrm{C}$ for 121 hours. Our results showed C. tropicalis sp. T-A's zinc content was $19.153 \mathrm{mg} / \mathrm{g}$ dry weight, with a relative bioavailability in rats of $173 \%$ when compared with traditional zinc supplements. Our study suggests that $C$. tropicalis sp. T-A could be exploited for use as a potential zinc supplement.
\end{abstract}

Keywords: zinc enrichment; Candida sp.; relative bioavailability.

Practical Application: New effective organic zinc supplements.

\section{Introduction}

$\mathrm{Zinc}(\mathrm{Zn})$ is one of the most essential and indispensable trace elements in cells (Chasapis et al., 2012). It plays an important role in numerous enzyme systems and is involved in multiple biological pathways such as enzymatic catalysis, redox regulation, cellular signal transduction, the immune system and neurons (Zhang et al., 2014). In the immune system, zinc is essential for innate immunity (which is mediated by cell), phagocytosis, and the function of the immune-specific cells; neutrophils, natural killer cells, and macrophages. The growth of $\mathrm{B}$ and $\mathrm{T}$ cells is adversely affected by zinc deficiency (Prasad, 2014)-which shows that appropriate zinc nutrition is important for human health (Hess et al., 2009). It was believed that zinc deficiency in humans could lead to significant clinical disorders (Prasad, 2013), such as growth retardation, bullous pustular dermatitis, emotional disorder and cell mediated 54 immune dysfunctions (Prasad, 2008). Some studies have shown that zinc supplementation can reduce the incidence and duration of infectious diseases such as Staphylococcus aureus mediated pneumonia and Escherichia coli induced urinary tract infections (Prasad, 2008).

Zinc supplementation (using zinc sulfate, zinc gluconate, etc.) is used to prevent and treat zinc deficiency. Microbial transformation is one of the most important methods used to assist zinc supplementation and Saccharomyces cerevisiae has been often used as a delivery vehicle for trace elements supplements because of its ability to accumulate metals and convert inorganic metals into organic species (Wang et al., 2011; Zhang et al., 2014). Some studies have shown that the zinc in zinc-enriched yeast has higher bioavailability than other supplements such as zinc sulfate and zinc gluconate (Tompkins et al., 2007), and also has lower toxicity (Wang et al., 2011). Additionally, yeast is also a better source of proteins, essential amino-acids, and vitamins (Wang et al., 2011). Vesna Stehlik-Tomas et al. reported on the enrichment of zinc, copper $(\mathrm{Cu})$ and manganese $(\mathrm{Mn})$ in yeast S. cerevisiae (Vesna et al., 2004), and concluded that S. cerevisiae is a good model microbe for studying metal transport in cells (Vesna et al., 2004).

In addition to $S$. cerevisiae, some Suilloid ectomycorrhizal fungi (like S. luteus) are also tolerant to zinc (Colpaert et al., 2005), and some macrofungi (mushrooms) such as Russula atropurpurea were described as highly zinc-accumulating species (Borovička \& Řanda, 2007). Another metal tolerant macrofungi group is white rot fungi which grows on wood and has been confirmed to enrich metals such as cadmium $(\mathrm{Cd})$, iron $(\mathrm{Fe}), \mathrm{Zn}$, and $\mathrm{Cu}$, and transport these metals from the wood to their fruit bodies (Gonen Tasdemir et al., 2008). These microorganisms might be used not only as a trace element supplement similar to $S$. cerevisiae, but could also be used for the removal of heavy metals in industrial and municipal water, in fact there are already some reports on large fungi being used in remediation studies of contaminated water (Gonen Tasdemir et al., 2008).

In our previous studies, we have shown that Fusarium oxysporum has greater accumulation of zinc, with a higher bioavailability than the supplement zinc gluconate (Zhang et al., 2014). Following on from this, we have conducted extensive screening and discovered a new strain belonging to the genus Candida, which also possess

${ }^{1}$ School of Life Science and Engineering, Lanzhou University of Technology, Key Laboratory of Screening and Processing in new Tibetan medicine of Gansu Province, Gansu, P.R. China

${ }^{2}$ Drug Evaluation and Certification Center of Gansu Drug Administration, Lanzhou, China

*Corresponding author: biodrug@163.com

\#These authors contributed equally to this work. 
the zinc enriching activity and in this paper, we describe this novel yeast species and examine its ability to enrich zinc.

\section{Materials and methods}

\subsection{Materials and regents}

Adenine, Guanine, Cytosine, Thymine and 2-carboxy-2'-cyano5 '-sulfobenzoic acid monosodium salt were obtained from Jingchun Biochemical Technology Company (Shanghai, China). HPLC grade methanol and were obtained from Tianjin Deen Chemical Reagent Company. Escherichia coli DH5a strain was deposited in the Center of Industrial Culture Collection, Gansu, China (collection number GSICC 51805). Zinc gluconate was obtained from Baiyunshan Pharmaceutical Company (Product batch number: 140601, Guangzhou, China).

\subsection{Isolation of microbes with high zinc tolerance}

The zinc enriched strain (C. tropicalis sp. T-A) was isolated from the soil in steel plant production areas, mineral accumulation areas, and sedimentation areas of Lanzhou in Gansu province, China. $1 \mathrm{~g}$ soil samples were dissolved in $10 \mathrm{~mL}$ of sterile water and filtered to remove insoluble matter. $1 \mathrm{ml}$ of supernatant was added to $100 \mathrm{~mL}$ each of rose bengal liquid medium (peptone $5 \mathrm{~g}$, glucose $10 \mathrm{~g}, \mathrm{~K}_{2} \mathrm{HPO}_{4} 1 \mathrm{~g}, \mathrm{MgSO}_{4} \cdot 7 \mathrm{H}_{2} \mathrm{O} 0.5 \mathrm{~g}$, rose bengal sodium salt $0.03 \mathrm{~g}$, chloramphenicol $0.1 \mathrm{~g}$, water $1000 \mathrm{~mL}$, $\mathrm{pH}$ 7.2 7.4), beef extract peptone medium (beef extract $3.0 \mathrm{~g}$, peptone $10.0 \mathrm{~g}, \mathrm{NaCl} 5.0 \mathrm{~g}$, water $1000 \mathrm{~mL}, \mathrm{pH} 7.4 \sim 7.6)$, and Gause's synthetic medium $\left(\mathrm{KNO}_{3} 1 \mathrm{~g}\right.$, soluble starch $20 \mathrm{~g}, \mathrm{~K}_{2} \mathrm{HPO}_{4} 0.5 \mathrm{~g}$, $\mathrm{MgSO}_{4} \cdot 7 \mathrm{H}_{2} \mathrm{O} 0.5 \mathrm{~g}, \mathrm{NaCl} 0.5 \mathrm{~g}, \mathrm{FeSO}_{4} 0.01 \mathrm{~g}$, water $1000 \mathrm{~mL}$, $\mathrm{pH} 7.2 \sim 7.4$ ) with $800 \mathrm{mg} / \mathrm{L} \mathrm{Zn} \mathrm{(II)} \mathrm{in} \mathrm{a} 500 \mathrm{~mL}$ Erlenmeyer flask, and cultured at $28^{\circ} \mathrm{C}, 37^{\circ} \mathrm{C}, 37^{\circ} \mathrm{C}$ respectively at $200 \mathrm{r} / \mathrm{min}$ in a rotary shaker. The strains that grow well from the preliminary screening were named the zinc enriched strains, and were then inoculated into rose bengal solid medium, beef extract peptone medium and Gause's synthetic medium containing zinc ions $\left(\mathrm{Zn}^{2+}\right)$ at $4000 \mathrm{mg} / \mathrm{L}, 6000 \mathrm{mg} / \mathrm{L}, 8000 \mathrm{mg} / \mathrm{L}$, and $10000 \mathrm{mg} / \mathrm{L}$ and cultured in the same conditions as above.

\subsection{Determination of zinc content}

The strain with the highest zinc enrichment was cultured in rose bengal medium containing zinc ions at $10000 \mu \mathrm{g} / \mathrm{mL}$ for 5 days. The culture was centrifuged at $5000 \mathrm{r} / \mathrm{min}$ for $10 \mathrm{~min}$, the cells washed 6 times with $0.9 \%$ sodium chloride solution to help remove unbound iron, and the collected cells were then dried at $60^{\circ} \mathrm{C}$ and placed in a digestion tube, then digested until colorless and transparent using a solution of concentrated nitric and perchloric acids (4:1, v/v), and made up to a final volume of $50 \mathrm{~mL}$ with the acid mix diluted. $30 \mathrm{~mL}$ of distilled water was added to $1 \mathrm{~mL}$ of diluent obtained from the previous step, which was added into $\mathrm{pH}$ 8.8 boric acid-potassium chloride-sodium hydroxide buffer $(37.3 \mathrm{~g}$ potassium chloride, $31 \mathrm{~g}$ boric acid and $8.34 \mathrm{~g}$ sodium hydroxide were dissolved in $60 \sim 80^{\circ} \mathrm{C}$ water, cooled down, to a final volume of $1 \mathrm{~L}$ ) (Zhang et al., 2015). $2 \mathrm{~mL}$ of $0.2 \%$ zincon monosodium salt (2-carboxy-2'-cyano-5'-sulfobenzoic acid monosodium salt, $0.2 \mathrm{~g}$ of zincon was added to $2 \mathrm{~mol} / \mathrm{L}$ sodium hydroxide, and was diluted to $100 \mathrm{~mL}$ ) was added and the absorbance was measured at
$620 \mathrm{~nm}$ using a UV-visible spectrophotometer (UV-9200, Beijing Ruili Analytical Instrument Company) and the amount of zinc calculated using Angel Maqulelra's method (Maquieira et al., 1994).

\subsection{Phenotypic characteristics and molecular identification}

C. tropicalis sp. T-A was purified by plating on rose bengal medium, and cultured at $28^{\circ} \mathrm{C}$ for 5 days until a single colony appeared. The phenotypic characteristics were then observed and described according to the methods used by Kurtzman et al. (2011). Total DNA of C. tropicalis sp. T-A was extracted using a modified version of Lu's method (Lu et al., 2004). Briefly, C. tropicalis sp. T-A was inoculated into rose bengal liquid medium, cultured at $28^{\circ} \mathrm{C}$ for 5 days, centrifuged at $5000 \mathrm{r} / \mathrm{min}$ for $5 \mathrm{~min}$, washed twice with PBS, and then washed twice with distilled water to collect the cells. The Ezup column fungal genomic DNA extraction kit was used to extract the total DNA. 18S rDNA was amplified by PCR using the primers $2234 \mathrm{C}$ and $3126 \mathrm{~T}$. The following thermal cycling program was used; 32 cycles of $3 \mathrm{~min}$ at $94{ }^{\circ} \mathrm{C}, 30 \mathrm{~s}$ at $94{ }^{\circ} \mathrm{C}, 30 \mathrm{~s}$ at $56^{\circ} \mathrm{C}, 50 \mathrm{~s}$ at $72{ }^{\circ} \mathrm{C}$, followed by $7 \mathrm{~min}$ at $72{ }^{\circ} \mathrm{C}$. The amplified PCR products were separated by $1 \%$ agarose gel electrophoresis and sent to Shanghai Biotech Bioengineering Technology Services for sequencing (Zhang et al., 2014). After obtaining the sequence, a BLAST search was performed and 10 strain sequences with similar homology were found (Altschul et al., 1990). Phylogenetic analyses were performed using ClustalX (Thompson et al., 1997), and phylogenetic trees were constructed using the neighbor-joining method (Saitou \& Nei, 1987). (GenBank accession number: MN124747)

\subsection{Determination of the $G+C$ content}

For this experiment, the Escherichia coli strain DH5a was selected as the standard strain for measuring GC content, and the DNA was extracted by Ezup column bacterial genomic DNA extraction kit (Sangon Biotech, Shanghai, China). The total DNA from $C$. tropicalis sp. T-A was extracted by the method described previously (Lu et al., 2004). The $\mathrm{G}+\mathrm{C}$ content was measured by the same method as Mesbah et al. (Wu et al., 2005) using reversed-phase HPLC. The HPLC system (JASCO, Kyoto, Japan) consisted of a PU-2086 pump, a 6-valve sample injection port fitted with a final volume sample loop of $20 \mu \mathrm{L}$ and a UV-2075 detector. Chromatographic separation was achieved on a reversed-phase C18 column (Wu et al., 2005) (SinoChrom ODS-BP, $4.6 \mathrm{~mm} \times 250 \mathrm{~mm}, 5.0 \mu \mathrm{m}$, Elite, Dalian, China) protected by a C18 guard column (ODS $4.6 \mathrm{~mm} \times 10 \mathrm{~mm}$, $15.0 \mu \mathrm{m}$, Elite, Dalian, China). The chromatographic conditions were as follows; the mobile phase was a mixture of $20 \mathrm{mmol} / \mathrm{L} \mathrm{KH}_{2} \mathrm{PO}_{4}$ buffer (pH 5.6)-methanol (90:10, v/v) (Wu et al., 2005) filtered with a G5 core funnel and degassed for $15 \mathrm{~min}$. Ultraviolet detection wavelength was $260 \mathrm{~nm}$, the flow-rate was $1.0 \mathrm{~mL} / \mathrm{min}$ (Wu et al., 2005) and the injection volume was $10 \mu \mathrm{L}$. Before sample injection, the column was equilibrated with the mobile phase for $1 \mathrm{~h}$, and the sample filtered with a $0.2 \mu \mathrm{m}$ filter.

\subsection{Assimilation of carbon compounds by strain C. tropicalis sp. T-A}

To physiologically characterize the strains, the identification of carbon source assimilation was performed using the fungi 
assimilation test identification plate (Byxbio, Changzhou, China). 12 different carbon compounds were tested for utilization; glucose, galactose, xylose, sucrose, sorbitol, lactose, raffinose, rhamnose, pine triose, inositol, cellobiose, and maltose. The results were compared with the Yeast Classification Manual.

\subsection{Evaluation of factors influencing strain growth}

To evaluate the effect of zinc ion concentration on the growth of strains, $100 \mathrm{~mL}$ of rose bengal liquid medium was prepared in $500 \mathrm{~mL}$ Erlenmeyer flasks, then sterilized. C. tropicalis sp. T-A $(1 \%, \mathrm{v} / \mathrm{v})$ was inoculated into the sterilized medium containing zinc concentrations of $6000 \mathrm{mg} / \mathrm{L}, 8000 \mathrm{mg} / \mathrm{L}$, and $10000 \mathrm{mg} / \mathrm{L}$, and incubated at $28^{\circ} \mathrm{C}$ for $120 \mathrm{~h}$. The cell concentration at $\mathrm{OD}_{600}$ and zinc content were determined as described above.

The initial $\mathrm{pH}$ of YPD liquid medium (yeast extract $10 \mathrm{~g}$, peptone $20 \mathrm{~g}$, glucose $20 \mathrm{~g}$, water $1000 \mathrm{~mL}$ ) was adjusted to 4.0, 5.0, 6.0, 7.0, 8.0, 9.0 with $\mathrm{HCl}$ and $\mathrm{NaOH}$, and the zinc ion $\left(\mathrm{Zn}^{2+}\right)$ concentration of the medium was adjusted to $8000 \mathrm{mg} / \mathrm{L}$. C. tropicalis sp. T-A $(1 \%, \mathrm{v} / \mathrm{v})$ was inoculated into $100 \mathrm{~mL}$ of the YPD medium, followed by shaking at $28{ }^{\circ} \mathrm{C}$ for $120 \mathrm{~h}$. The cell concentration at $\mathrm{OD}_{600}$ and zinc content were determined as described above to evaluate the effect of $\mathrm{pH}$ on the growth.

C. tropicalis sp. T-A was inoculated into $100 \mathrm{~mL} \mathrm{YPD} \mathrm{liquid}$ medium containing $8000 \mathrm{mg} / \mathrm{L} \mathrm{Zn}^{2+}$ at temperatures of $15^{\circ} \mathrm{C}$, $20^{\circ} \mathrm{C}, 24^{\circ} \mathrm{C}, 28^{\circ} \mathrm{C}, 30^{\circ} \mathrm{C}, 35^{\circ} \mathrm{C}$ and $40^{\circ} \mathrm{C}$. The cell concentration at $\mathrm{OD}_{600}$ and zinc content were measured after $120 \mathrm{~h}$ to determine the effect of temperature on the growth. To determine the effect of culture time on the strains, $C$. tropicalis sp. T-A was inoculated into $100 \mathrm{~mL}$ YPD liquid medium containing $8000 \mathrm{mg} / \mathrm{L} \mathrm{Zn}^{2+}$, were incubated at $28^{\circ} \mathrm{C}$ for $0-156 \mathrm{~h}$. The absorbance and zinc content were measured as described above.

\subsection{Bioavailability of organic bound zinc}

The organic bound zinc was obtained as per our previous method. Briefly, the strain C. tropicalis sp. T-A with high zinc enriched conversion capacity was cultivated and collected by centrifuging at $5000 \mathrm{r} / \mathrm{min}$ for $10 \mathrm{~min}$, washed 6 times with $0.9 \%$ sodium chloride solution, placed in a dialysis bag, and dialyzed for 48 hours until no free zinc was detected.

Twelve healthy female Wistar rats, weighing between 200 g-220 g, were purchased from the Experimental Animal Center of Gansu College of Traditional Chinese Medicine. According to the requirements of the National Act on the Use of Experimental Animals (People's Republic of China), the protocols used in these animal experiments were approved by the Animals Ethics Committee of Lanzhou University of Technology. All rats were housed at room temperature $\left(25 \pm 2{ }^{\circ} \mathrm{C}\right)$ with a $12 \mathrm{~h}$ light-dark cycle, fed a standard laboratory diet and were given deionized water.
The rats were randomly divided into two groups, one treated with the zinc enriched strain $C$. tropicalis sp. T-A, the other group was treated with zinc gluconate. The rats were fasted overnight for $12 \mathrm{~h}$ before the experiment. Each rat was intragastrically administered $\mathrm{Zn}$ (II) at a dose of $10 \mathrm{mg} / \mathrm{Kg}$ body weight. Whole blood samples were collected from the retro-orbital plexus before and after oral administration at $0,5,15,30,45,60,90,120$ and 180 minutes. Each blood sample was treated with a $14 \mathrm{M}$ nitric and $10 \mathrm{M}$ perchloric acid mixture $(4: 1, \mathrm{v} / \mathrm{v})$ by boiling it until a clear solution was obtained. The zinc content was measured using an atomic absorption spectrophotometer (AAS-3200, Shanghai, China) (Zhang et al., 2014). The measurement conditions were: lamp current $5 \mathrm{~mA}$, wavelength $248.3 \mathrm{~nm}$, nip $0.2 \mathrm{~nm}$, air flow $13.5 \mathrm{~L} / \mathrm{min}$, acetylene flow $2.00 \mathrm{~L} / \mathrm{min}$. The zinc ion content of the blood was processed by DAS3.0 software to obtain the drug-time curve and pharmacokinetic parameters of the organic bound zinc in rats.

\section{Results}

\subsection{Determination of zinc content}

12 strains were able to grow well on medium containing zinc ions at $10000 \mu \mathrm{g} / \mathrm{mL}$, and their intracellular zinc content was determined and summarized in Table 1. Different zinc enriched strains showed different capabilities for inorganic zinc conversion. Strain T-B showed lower zinc conversion capacity and the intracellular zinc content was $12.764 \mathrm{mg} / \mathrm{g}$. Among them, a strain named C. tropicalis sp. T-A recorded the highest intracellular zinc content of $19.153 \mathrm{mg} / \mathrm{g}$ and was used in later experiments.

\subsection{Phenotypic characteristics and molecular identification}

C. tropicalis sp. T-A showed red single colonies when grown in rose bengal medium, the surface was smooth and viscous, and the edges were neat and when observed under the microscope, the cells were spherical or oval (Figure 1). The sequence obtained from the PCR of $C$. tropicalis sp. T-A genomic DNA was compared with the Genbank database using BLAST and showed that the strain has $87 \%$ homology with the $18 \mathrm{~S}$ rDNA sequence of Candida tropicalis. According to the results of $18 \mathrm{~S}$ rDNA sequencing a phylogenetic tree was constructed (Figure 1).

\subsection{Determination of $\mathrm{G}+\mathrm{C} \mathrm{mol \%}$}

$\mathrm{G}+\mathrm{C}$ content was determined to identify the species-genus relationship of microorganisms. Table 2 shows the $\mathrm{G}+\mathrm{C}$ mol\% measurements of the standard and sample strains tested. The $\mathrm{G}+\mathrm{C}$ mol\% content of the standard strain, DH5a, in this experiment was $52.61 \%$, which did not vary much from other published values (Cui et al., 2010). The $\mathrm{G}+\mathrm{C}$ mol\% of $C$. tropicalis sp. $\mathrm{T}-\mathrm{A}$ is $88 \%$, and considering that typical yeast $\mathrm{G}+\mathrm{C} \mathrm{mol} \%$ is

Table 1. Determination of zinc content in different zinc enriched strains.

\begin{tabular}{|c|c|c|c|c|c|c|c|c|c|c|c|c|}
\hline $\begin{array}{l}\text { Zinc enriched } \\
\text { strains }\end{array}$ & G-S & G-T & T-2 & T-1 & $\mathrm{T}-\mathrm{A}$ & $\mathrm{T}-\mathrm{C}$ & S-B & H-S & T-B & $\mathrm{T}-10$ & $\mathrm{~N}-2$ & $\mathrm{~N}-\mathrm{C}$ \\
\hline $\begin{array}{l}\text { Zinc content } \\
(\mathrm{mg} / \mathrm{g})\end{array}$ & 16.032 & 13.478 & 14.896 & 13.275 & 19.153 & 17.850 & 17.630 & 14.095 & 12.764 & 18.099 & 14.073 & 15.730 \\
\hline
\end{tabular}




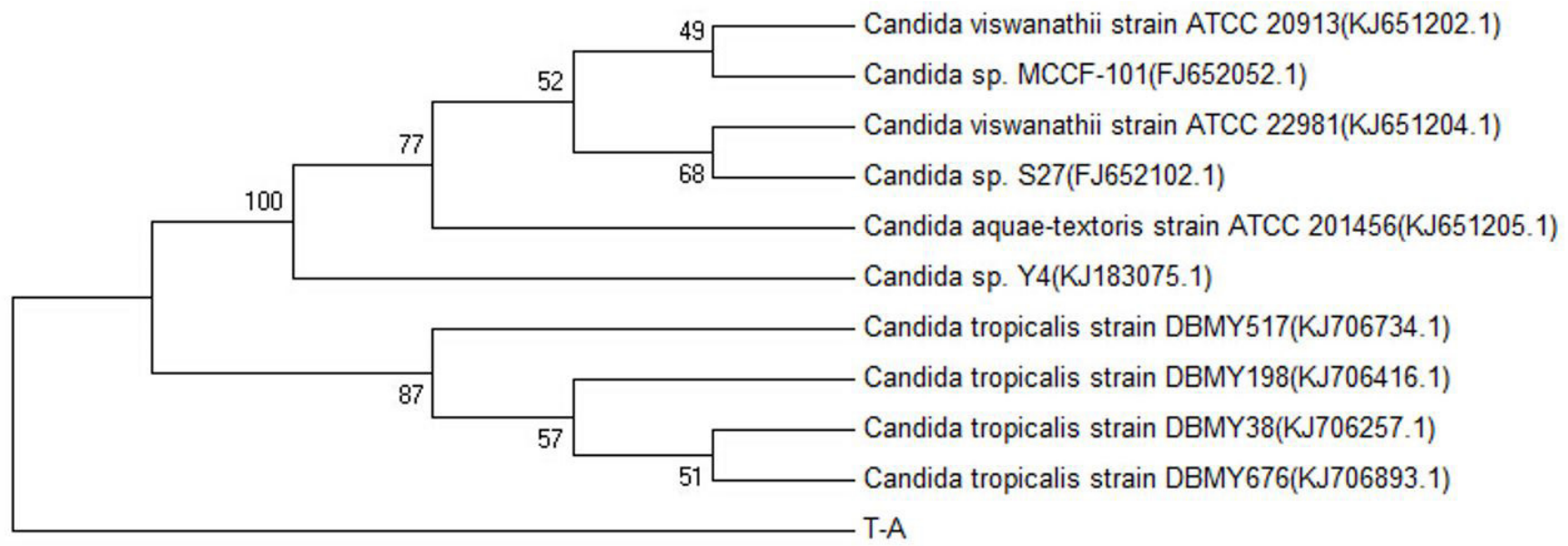

Figure 1. Phylogenetic tree of $18 \mathrm{~S}$ rDNA homology comparison of zinc enriched strain C. tropicalis sp. T-A.

Table 2. Determination of the $\mathrm{G}+\mathrm{C}$ mol\% of strains.

\begin{tabular}{lcc}
\hline \multicolumn{1}{c}{ Sample } & Base & $\mathrm{G}+\mathrm{C} \mathrm{mol} \%$ \\
\hline \multirow{3}{*}{ Standard strain } & $\mathrm{C}$ & \\
& $\mathrm{G}$ & 52.61 \\
& $\mathrm{~T}$ & \\
$\mathrm{~A}$ & \\
The strain C. & $\mathrm{C}$ & \\
tropicalis sp. T-A & $\mathrm{G}$ & \\
& $\mathrm{T}$ & \\
\hline
\end{tabular}

Note: A: Adenine, G: Guanine, C: Cytosine, T: Thymine.

usually between $50 \%$ and $70 \%$, it suggests that C. tropicalis sp. T-A may be a novel strain.

\subsection{Assimilation of carbon compounds by strain C. tropicalis sp. $T-A$}

Carbon source assimilation is a method of distinguishing different yeast species by observing the differences in the ability of a species to use an organic compound as a single major carbon source. From Table 3, glucose (GLU), galactose (GAL), xylose (XYL), sucrose (SAC), lactose (LAC), pine triose (MlZ) and maltose (MAL) were assimilated, sorbitol (SOR), raffinose (RAF), rhamnose (RHA), inositol (INO) and cellobiose (CEL) were not. After comparison with the Yeast Classification Manual, the carbon assimilation results were similar to those of $C$. tropicalis, with only the lactose (LAC) result different, indicating that C. tropicalis sp. T-A may have a close kinship with C. tropicalis.

\subsection{Factors influencing zinc-enriched strain growth}

C. tropicalis sp. T-A was cultured in a medium with a zinc ion concentration of 6000-10000 mg/L. As shown in Figure 2A, with the increase of zinc ion concentration, C. tropicalis sp. T-A's zinc enrichment increased and growth improved. At a zinc
Table 3. Assimilation of carbon compounds.

\begin{tabular}{cc}
\hline Different carbon source & The strain C. tropicalis sp. T-A \\
\hline GLU & + \\
GAL & + \\
XYL & + \\
SAC & - \\
SOR & + \\
LAC & - \\
RAF & - \\
RHA & + \\
MlZ & + \\
INO & - \\
CEL & - \\
MAL & + \\
\hline
\end{tabular}

(+) positive; (-) negative. Note: GLU glucose, GAL galactose, XYL xylose, SAC sucrose, SOR Sorbitol, LAC lactose, RAF raffinose, RHA rhamnose, MlZ pine triose, INO inositol, CEL cellobiose, MAL maltose.

concentration of $8000 \mathrm{mg} / \mathrm{L}$, C. tropicalis sp. T-A's intracellular zinc content was highest and growth most improved. In addition to this, with the increase of zinc ion concentration in the medium, the biomass decreased slightly while the enrichment amount did not change, indicating that a high enough concentration of zinc can inhibit the growth $C$. tropicalis sp. T-A. In this study, the optimum zinc ion concentration in the growth medium of C. tropicalis sp. T-A was judged to be $8000 \mathrm{mg} / \mathrm{L}$ (Figure 2A).

As shown in Figure 2B, C. tropicalis sp. T-A could accumulate zinc in a range of temperatures $\left(15 \sim 40{ }^{\circ} \mathrm{C}\right)$ and grew best with greatest zinc enrichment at $28{ }^{\circ} \mathrm{C}$. As shown in Figure $2 \mathrm{C}$, C. tropicalis sp. T-A was able to grow in a $\mathrm{pH}$ range between 4.0 and 9.0. With an increase in $\mathrm{pH}$, the enrichment of zinc increases to a peak at $\mathrm{pH} 5$ after which enrichment decreases. As shown in Figure 2D, the biomass and enrichment of C. tropicalis sp. T-A increased gradually with time. At $121 \mathrm{~h}$, the intracellular zinc 
$\mathbf{A}$
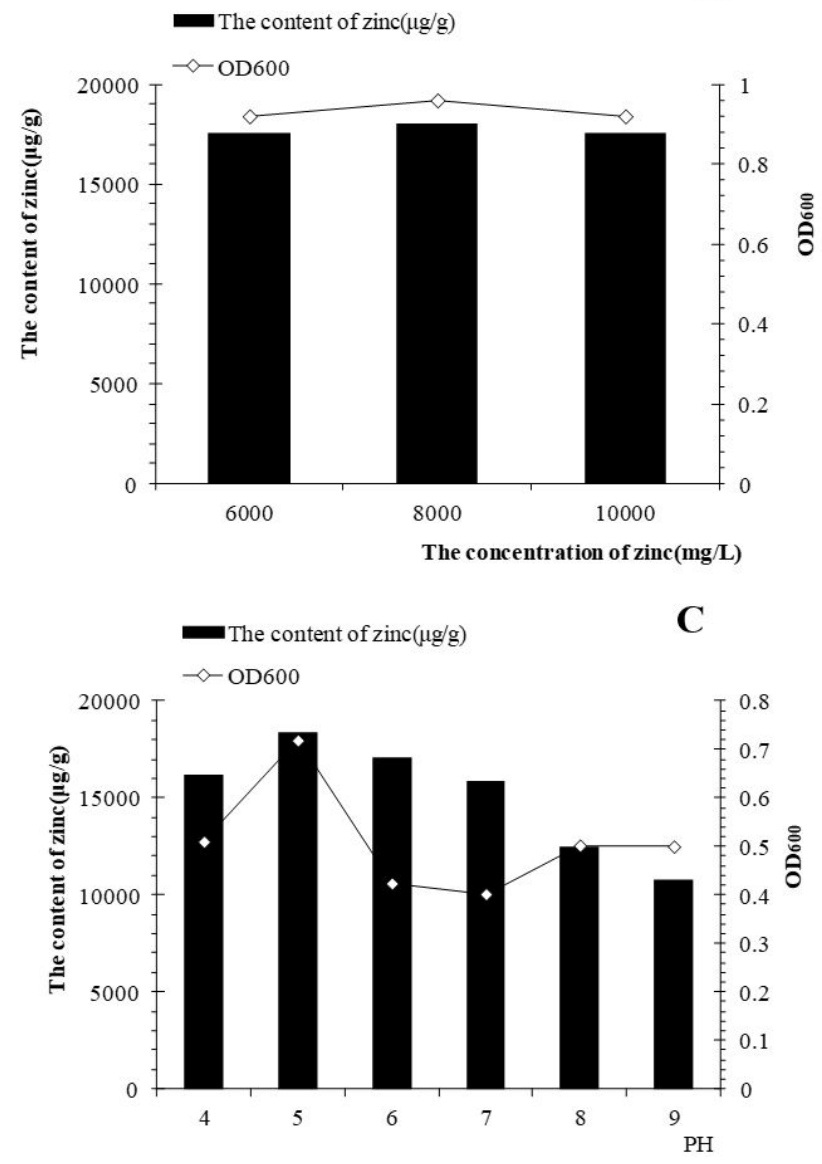

B

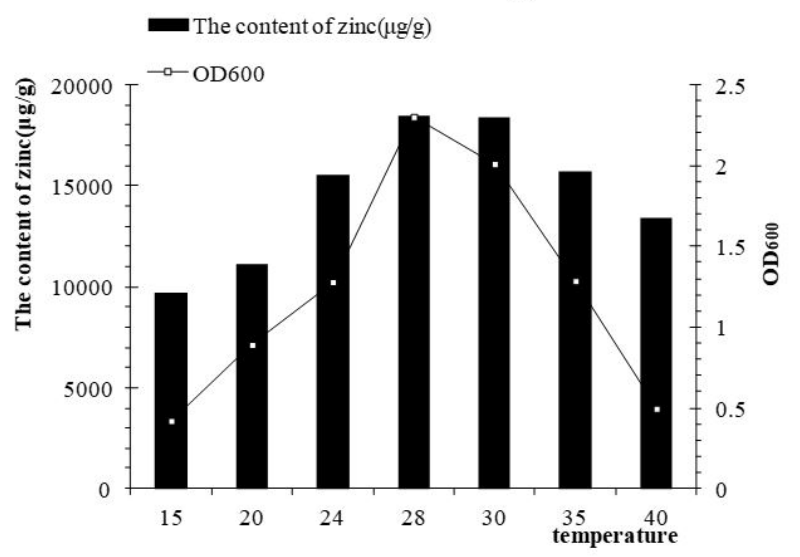

D

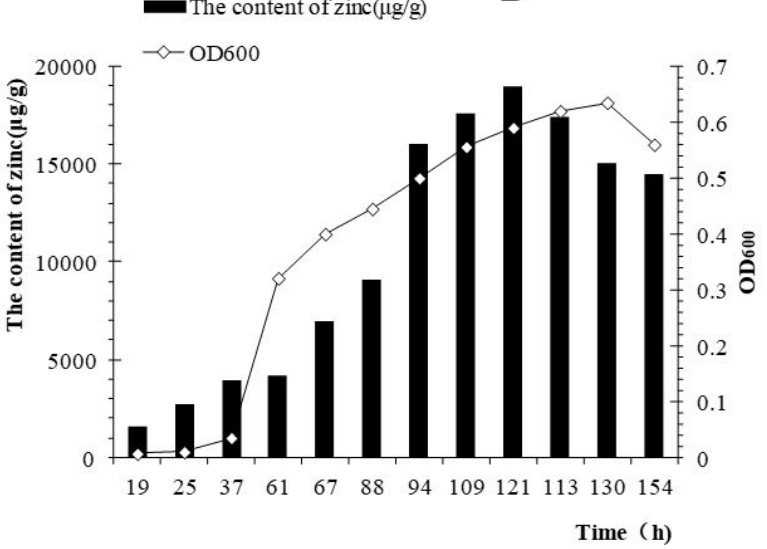

Figure 2. Determination of optimum growth conditions of $C$. tropicalis sp. T-A grown on rose bengal medium. Here, 1A, 1B, 1C and 1D represent optimum zinc ion concentration, $\mathrm{pH}$, temperature, and incubation time respectively.

content of the strain was at its peak, and the cell concentration reached its peak at $130 \mathrm{~h}$. Although there is a difference in the times of the two peaks, given that the growth of the cells in zinc-containing medium is relatively slow the optimal incubation time was decided to be the zinc content peak at $121 \mathrm{~h}$.

\subsection{Bioavailability of organic bound zinc in rats}

A pharmacokinetic study was used to evaluate the bioavailability of different forms of zinc. After oral administration of $C$. tropicalis sp. T-A (bound zinc) and zinc gluconate, the plasma concentration-time profiles were determined (Figure 3), and the pharmacokinetic parameters were calculated and summarized in Table 4.

After oral administration of C. tropicalis sp. T-A and zinc gluconate, plasma zinc levels declined in a bi-exponential fashion. The plasma zinc concentration versus time data was fitted to the classical two-compartment open model for kinetic analysis which consists of central and peripheral compartments (Figure 3). After oral administration, zinc was absorbed rapidly in the rat gastrointestinal tract, the Cmax and Tmax values of $C$. tropicalis sp. T-A and zinc gluconate were $40.33,18.67 \mu \mathrm{g} / \mathrm{mL}$ and $39.03,43.22 \mathrm{~min}$, respectively. The $\mathrm{T}_{1 / 2 \mathrm{k}}$ of C. tropicalis sp. T-A and zinc gluconate were 135

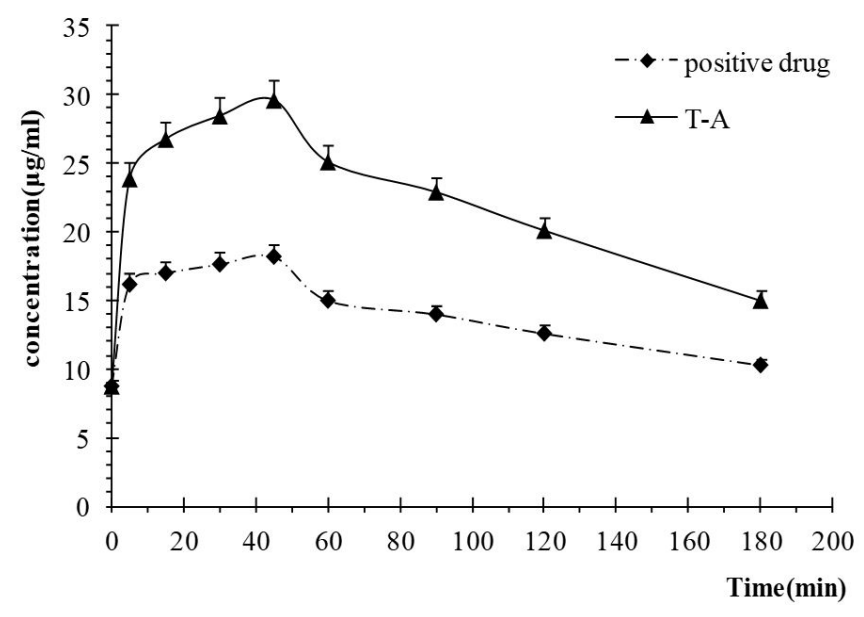

Figure 3. Mean blood concentration-time profiles of C. tropicalis sp. T-A and zinc gluconate following an oral administration of $C$. tropicalis sp. T-A and zinc gluconate to rats at a dose of $10 \mathrm{mg} \mathrm{Zinc}(\mathrm{II}) / \mathrm{Kg}$ body weight.

and 140 min respectively, suggesting that the organic zinc and zinc gluconate used in this study showed similar absorption characteristics. The AUC (Area Under the Curve) of the two were 5630.81 and $3259.24 \mu \mathrm{g} / \mathrm{mL}^{\star}$ min respectively (Table 4 , 
Table 4. Pharmacokinetic parameters in rats after oral administration of C. tropicalis sp. T-A and zinc gluconate.

\begin{tabular}{cccc}
\hline Parameters & Units & C. tropicalis sp. T-A & Zinc Gluconate \\
\hline AUC & $\mu \mathrm{g} / \mathrm{ml} . \mathrm{min}$ & $5630.81 \pm 1078.05^{*}$ & $3259.24 \pm 1374.43$ \\
Tmax & Min & $39.03 \pm 12.12$ & $43.22 \pm 12.45$ \\
Cmax & $\mu \mathrm{g} / \mathrm{ml}$ & $40.33 \pm 7.01^{*}$ & $18.67 \pm 6.98$ \\
$\mathrm{~T}_{1 / 2 \mathrm{k}}$ & $\mathrm{Min}$ & $135 \pm 16.47$ & $140 \pm 18.61$ \\
\hline
\end{tabular}

AUC is the area under the plasma concentration-time curve; Tmax is the maximum concentration; Cmax is the maximum plasma concentration; $\mathrm{T}_{1 / 2 \mathrm{k}}$ is the elimination half-life; Values are expressed as means \pm standard deviation $(n=6) ;{ }^{*}$ demonstrates a significant difference from zinc gluconate control group, $\mathrm{P}<0.05$

Figure 3), the AUC and Cmax of C. tropicalis sp. T-A were significantly difference from zinc gluconate group $(\mathrm{P}<0.05)$, and the relative bioavailability of AUC test/AUC zinc gluconate was $175 \%$, which showed that the zinc from C. tropicalis sp. $\mathrm{T}$-A had better bioavailability than zinc gluconate in rats.

\section{Discussion}

The utilization of microorganisms to convert inorganic zinc into organic zinc is an important direction for the study and development of trace element zinc supplements. In order to screen for a highly resistant and more enriched zinc strain, we selected a zinc ion concentration of $800 \mathrm{mg} / \mathrm{L}$ as the primary screening point because $S$. cerevisiae, as a model microorganism, did not grow in medium with zinc ion concentration of $600 \mathrm{mg} / \mathrm{L}$ (Xue et al., 2003). It was found that the microorganisms that can convert zinc are mainly fungi, and some actinomycetes bacteria to a lesser extent.

After a wide ranging screening, the strain C. tropicalis sp. T-A was found and shown to have the highest zinc ion enrichment concentration. C. tropicalis sp. T-A's $18 \mathrm{~S}$ rDNA sequencing results showed highest homology (87\%) with C. tropicalis. The content of $\mathrm{G}+\mathrm{C}$ mol\% determined by high performance liquid chromatography (HPLC) was $88.42 \%$ which suggest that C. tropicalis sp. T-A may be a new strain.

Candida sp., which belongs to the ascomycetous yeasts, is an extraordinary heterogeneous and conspicuous genus in the Debaryomycetaceae and includes; Lodderomyces/Candida albicans, Candida glaebosa clade, Candida kruisii clade and Candida tanzawaensis clade (Daniel et al., 2014). Candida sp. contains 163 species and covers anamorphic ascomycetous yeasts which propagate by multilateral budding and which are not attributed to morphologically distinct genera or physiologically distinct genera, such as C. tropicalis, Candida albicans and the ascosporic species Lodderomyces elongisporus (de Llanos Frutos et al., 2004).

Several Candida sp. strains, including C. maltosa, C. tropicalis, and C. utilis, have been found to be able to degrade hydrocarbons and grow on crude oils and alkanes (Sutherland, 2004). Ramírez-Ramírez et al. (2004) reported that C. maltosa can tolerate $\mathrm{Cr}(\mathrm{VI})$ concentrations up to $100 \mu \mathrm{g} / \mathrm{mL}$ and has the ability to reduce $\mathrm{Cr}(\mathrm{VI})$. Candida argentea was highly resistant to both copper and silver according to Holland et al. (2011) and Khan et al. (2015) reported that Candida sp. PS33, isolated from industrial wastewater, was tolerant to $\mathrm{Pb}$ (up to $35 \mathrm{mM}$ ), As (up to $29 \mathrm{mM}$ ), $\mathrm{Cu}$ (up to $23 \mathrm{mM}$ ), $\mathrm{Cd}$ (up to $11 \mathrm{mM}$ ) and Cr (up to $8 \mathrm{mM}$ ).

Unlike previous reports (Wang et al., 2011; Zhang et al., 2014), in our study, dialysis bags were used to remove inorganic zinc. Organic zinc is a component that binds to macromolecular such as proteins and polysaccharides. This process was carried out mainly to ensure that organic zinc is obtained instead of a mixture of organic zinc and inorganic zinc (Wang et al., 2011; Zhang et al., 2014). Studies have shown the zinc-rich yeast strains selected by cross-breeding currently have a maximum zinc content of $9.3 \mathrm{mg} / \mathrm{g}$ dry cells (Guo et al., 2004). Moreover, Twenty-six kinds of Saccharomyces cerevisiae were also used to screen yeasts capable of simultaneously enriching iron and zinc. Among them, strain LN-17 had the best enrichment ability, and the enrichment amounts of iron and zinc reached 7.854 and $4.976 \mathrm{mg} / \mathrm{g}$ dry cells, respectively (Wang et al., 2011). In this study, the zinc enriched strain C. tropicalis sp. T-A resisted and grew well in medium with higher zinc content, and had a maximum zinc content as high as $19.153 \mathrm{mg} / \mathrm{g}$ dry cells. In addition, Candida tropicalis is used for the production of single-cell proteins in the feed industry (Gao et al., 2012), and the results of oral acute toxicity show that $C$. tropicalis sp. T-A is safe (Data not shown). Li et al. (2004) showed that Se-rich yeast can be optimized to achieve higher selenium content. This study only optimized zinc ion concentration, $\mathrm{pH}$, temperature, and culture time and with further study, the enrichment of zinc by $C$. tropicalis sp. T-A should reach higher levels.

\section{Conclusion}

The $18 \mathrm{~S}$ rDNA sequence alignment of the strain C. tropicalis sp. T-A showed that it had the highest homology (87\%) with C. tropicalis, and the $\mathrm{G}+\mathrm{C}$ mol\% determined by reverse high performance liquid chromatography was $88.42 \%$ which suggests that it might be a new strain. C. tropicalis sp. T-A has a high zinc concentration and is expected to be a useful target for research and exploitation as a new zinc supplement.

\section{Acknowledgements}

This research was supported by the program of National Natural Science Foundation of China under Grant (No. 31860004), Gansu province natural science fund (17JR5RA134) and the Fundamental Research Funds for Key Laboratory of Drug Screening and Deep Processing for Traditional Chinese and Tibetan Medicine of Gansu Province (No. 20180802).

\section{References}

Altschul, S. F., Gish, W., Miller, W., Myers, E. W., \& Lipman, D. J. (1990). Basic local alignment search tool. Journal of Molecular Biology, 215(3), 403-410. http://dx.doi.org/10.1016/S0022-2836(05)803602. PMid:2231712.

Borovička, J., \& Řanda, Z. (2007). Distribution of iron, cobalt, zinc and selenium in macrofungi. Mycological Progress, 6(4), 249-259. http:// dx.doi.org/10.1007/s11557-007-0544-y. 
Chasapis, C. T., Loutsidou, A. C., Spiliopoulou, C. A., \& Stefanidou, M. E. (2012). Zinc and human health: an update. Archives of Toxicology, 86(4), 521-534. http://dx.doi.org/10.1007/s00204-011-0775-1. PMid:22071549.

Colpaert, J. V., Adriaensen, K., Muller, L. A. H., Lambaerts, M., Faes, C., Carleer, R., \& Vangronsveld, J. (2005). Element profiles and growth in Zn-sensitive and Zn-resistant Suilloid fungi. Mycorrhiza, 15(8), 628634. http://dx.doi.org/10.1007/s00572-005-0009-6. PMid:16133247.

Cui, C. X., Li, P. F., Cao, W. R., Dai, M. X., \& Xia, Z. J. (2010). Determination of the DNA G+ C mol\% in type strain ST307 of prospectively new species of genus chromohalobacter by reversedphase high performance liquid chromatography. Biotechnology (Faisalabad), 20(5), 42-45.

Daniel, H. M., Lachance, M. A., \& Kurtzman, C. P. (2014). On the reclassification of species assigned to Candida and other anamorphic ascomycetous yeast genera based on phylogenetic circumscription. Antonie van Leeuwenhoek, 106(1), 67-84. http://dx.doi.org/10.1007/ s10482-014-0170-z. PMid:24748333.

de Llanos Frutos, R., Fernández-Espinar, M. T., \& Querol, A. (2004). Identification of species of the genus candida by analysis of the 5.8 $\mathrm{S}$ rRNA gene and the two ribosomal internal transcribed spacers. Antonie van Leeuwenhoek, 85(3), 175-185. http://dx.doi.org/10.1023/ B:ANTO.0000020154.56649.0f. PMid:15028869.

Gao, Y., Li, D. P., \& Liu, Y. (2012). Production of single cell protein from soy molasses using Candida tropicalis. Annals of Microbiology, 62(3), 1165-1172. http://dx.doi.org/10.1007/s13213-011-0356-9.

Gonen Tasdemir, F., Yamac, M., Cabuk, A., \& Yildiz, Z. (2008). Selection of newly isolated mushroom strains for tolerance and biosorption of zinc in vitro. Journal of Microbiology and Biotechnology, 18(3), 483-489. PMid:18388466.

Guo, X. N., Fu, X. H., He, X. P., \& Zhang, B. R. (2004). The screening of a zinc-enriched yeast strain and primary optimization of cultivation conditions. Acta Microbiologica Sinica, 44(2), 240-243.

Hess, S. Y., Lönnerdal, B., Hotz, C., Rivera, J. A., \& Brown, K. H. (2009). Recent advances in knowledge of zinc nutrition and human health. Food and Nutrition Bulletin, 30(1, Suppl), S5-11. http://dx.doi. org/10.1177/15648265090301S102. PMid:19472599.

Holland, S. L., Dyer, P. S., Bond, C. J., James, S. A., Roberts, I. N., \& Avery, S. V. (2011). Candida argentea sp. nov., a copper and silver resistant yeast species. Fungal Biology, 115(9), 909-918. http://dx.doi. org/10.1016/j.funbio.2011.07.004. PMid:21872188.

Khan, Z., Hussain, S. Z., Rehman, A., Zulfiqar, S., \& Shakoori, A. R. (2015). Evaluation of cadmium resistant bacterium, Klebsiella pneumoniae, isolated from industrial wastewater for its potential use to bioremediate environmental cadmium. Pakistan Journal of Zoology, 47(6), 1533-1543.

Kurtzman, C. P., Fell, J. W., Boekhout, T., \& Robert, V. (2011). Methods for isolation, phenotypic characterization and maintenance of yeasts. In C. P. Kurtzman, J. W. Fell \& T. Boekhout (Eds.), Yeasts (Chap. 7, pp. 87-110). USA: Elsevier. http://dx.doi.org/10.1016/B978-0444-52149-1.00007-0.

Li, A. F., Liu, Z. Q., Xu, N., Duan, S. S., \& Chen, M. (2004). Studies on fermentation of trace element Se-rich yeast. Journal of Jinan University, 25(5), 626-631.

Lu, H. Z., Jia, J. H., Wang, Q. M., \& Bai, F. Y. (2004). Candida asparagi sp. nov., Candida diospyri sp. nov. and Candida qinlingensis sp. nov., novel anamorphic, ascomycetous yeast species. International Journal of Systematic and Evolutionary Microbiology, 54(Pt 4), 1409-1414. http://dx.doi.org/10.1099/ijs.0.03055-0. PMid:15280322.
Maquieira, A., Elmahadi, H. A., \& Puchades, R. (1994). Use of Saccharomyces cerevisiae in flow injection atomic absorption spectrometry for trace metal preconcentration. Analytical Chemistry, 66(9), 1462-1467. http://dx.doi.org/10.1021/ac00081a017. PMid:8017632.

Prasad, A. S. (2008). Zinc in human health: effect of zinc on immune cells. Molecular Medicine (Cambridge, Mass.), 14(5-6), 353-357. http://dx.doi.org/10.2119/2008-00033.Prasad. PMid:18385818.

Prasad, A. S. (2013). Discovery of human zinc deficiency: its impact on human health and disease. Advances in Nutrition, 4(2), 176-190. http://dx.doi.org/10.3945/an.112.003210. PMid:23493534.

Prasad, A. S. (2014). Impact of the discovery of human zinc deficiency on health. Journal of the American College of Nutrition, 28(3), 357363. http://dx.doi.org/10.1016/j.jtemb.2014.09.002.

Ramírez-Ramírez, R., Calvo-Méndez, C., Avila-Rodríguez, M., Lappe, P., Ulloa, M., Vázquez-Juárez, R., \& Gutiérrez-Corona, J. F.. (2004). $\mathrm{Cr}(\mathrm{VI})$ reduction in a chromate-resistant strain of Candida maltosa isolated from the leather industry. Antonie van Leeuwenhoek, 85(1), 63-68. http://dx.doi.org/10.1023/B:ANTO.0000020151.22858.7f. PMid:15028877.

Saitou, N., \& Nei, M. (1987). The neighbor-joining method: a new method for reconstructing phylogenetic trees. Molecular Biology and Evolution, 4(4), 406-425. PMid:3447015.

Sutherland, J. B. (2004). Degradation of hydrocarbons by yeasts and filamentous fungi (Mycology Series, Vol. 21, pp. 443-455). Rome: FAO.

Thompson, J. D., Gibson, T. J., Plewniak, F., Jeanmougin, F., \& Higgins, D. G. (1997). The CLUSTAL_X windows interface: flexible strategies for multiple sequence alignment aided by quality analysis tools. Nucleic Acids Research, 25(24), 4876-4882. http://dx.doi.org/10.1093/ nar/25.24.4876. PMid:9396791.

Tompkins, T. A., Renard, N. E., \& Kiuchi, A. (2007). Clinical evaluation of the bioavailability of zinc-enriched yeast and zinc gluconate in healthy volunteers. Biological Trace Element Research, 120(1-3), 28-35. http://dx.doi.org/10.1007/s12011-007-0072-2. PMid:17916952.

Vesna, S. T., Vlatka, G. Z., Damir, S., Slobodan, G., \& Nada, V. (2004). Zinc, copper and manganese enrichment in yeast Saccharomyces cerevisae. Food Technology and Biotechnology, 42(2), 115-120.

Wang, Z., Zhang, J., Su, T. T., Guan, Z. F., \& Ji, M. (2011). Screening of iron- and zinc-enriched yeast strain and optimization of cultivation conditions. Preparative Biochemistry \& Biotechnology, 41(3), 278-286. http://dx.doi.org/10.1080/10826068.2010.539656. PMid:21660867.

Wu, Y., Li, H. Z., Ma, Y. P., \& Qiu, Z. Y. (2005). Determination of the $\mathrm{G}+\mathrm{C}$ mol\% of DNA in a novel strain of bifidobacterium bifidum by reversed-phase high performance liquid chromatogrephy. Journal of Southwest China Normal University, 30(1), 96-100.

Xue, D. H., Jin, H., \& Xiao, Y. (2003). Study on zinc yeast cultures and absorption and application. Progress in Biotechnology, 23(6), 72-75.

Zhang, X. G., Peng, Y. N., Li, X. R., Ma, G. D., \& Chen, X. Q. (2015). Screening of iron-enriched fungus from natural environment and evaluation of organically bound iron bioavailability in rats. Food Science and Technology (Campinas), 35(1), 58-65. http://dx.doi. org/10.1590/1678-457X.6454.

Zhang, X. G., Peng, Y. N., Li, X. R., Ma, G. D., \& Wang, M. G. (2014). Higher Bioavailability of Organic Bound Zinc from High ZincEnriched Fungi. International Journal for Vitamin and Nutrition Research, 84(5-6), 277-285. http://dx.doi.org/10.1024/0300-9831/ a000214. PMid:26255549. 